Manuel Joaquín Fernández González, Tamāra Pīgozne, Svetlana Surikova, Lubova Vasečko

University of Latvia, Latvia

\title{
VOCATIONAL EDUCATION INSTITUTION LEADERS' VIRTUES AND EDUCATIONAL LEADERSHIP PROFILE IN LATVIA: A PERSONALITY PERSPECTIVE OF EDUCATION QUALITY
}

\begin{abstract}
Considering the topicality of vocational education and training (VET) in Latvia, and the relevance of school leaders' personality and leadership abilities for education quality, the purpose of this research paper was to explore the associations between VET institution leaders' civic, intellectual, moral and performance virtues, and the different dimensions of their leadership (charismatic, cultural, emotional, formative, participatory, professional, administrative and anticipatory), using mixed methods research for exploring staff's and students' views about it.

Two groups of research questions guided the study: one about the pedagogical leadership dimensions: What are the most salient pedagogical leadership dimensions of three high-level Latvian VET institutions' leaders; what are the differences between students' and staff's opinions about how their institution leaders embody those dimensions?; and the other group of questions about the associations between leaders' virtues and leadership dimensions: Which leadership dimensions and virtues are more often associated in respondents' discourse about their institution leaders; and what are the differences between respondents' groups regarding these associations? Data collected in 3 high-quality VET institutions from different fields (tourism, sports and maritime education) were used for secondary analysis. The quantitative part of the study was based on 83 answers to the standardized questionnaire "Pedagogical Leadership and Quality of Education". The qualitative part of the study was based on seventeen semistructured interviews: 6 with leading staff, 5 with teachers and 6 with students. Latent content regarding leaders' virtues was explored using qualitative data analysis software AQUAD 7.
\end{abstract}


The most salient leadership dimensions were the 'professional', 'charismatic' and 'emotional' ones. School staff rated the 'professional', 'participatory' and 'cultural' dimensions statistically significantly higher than students. Unexpected associations were found between: leaders' civic virtues and 'charismatic' leadership dimension; intellectual virtues and 'emotional' dimension; and performance virtues and 'participatory' dimension and 'cultural' dimension. Differences among group opinions were also found regarding these associations: students praised VET institution leaders' virtues mostly while speaking about the 'charismatic' dimension of leadership, while leading staff and teachers did so while speaking about the 'emotional' dimension. Leading staff associated VET institution leaders' virtues also with the 'formative' dimension, while teachers - with the 'cultural' dimension.

These results offer an original picture of the specific features of character of the institution leaders and how they are associated with their leadership: these leaders were able to combine personal charisma with civic attitudes and neighbourliness, and to create an emotionally rewarding institutional atmosphere, using their personal acumen and good sense for leading the institution successfully. This study represents also an innovative methodological contribution for investigating educational institution leaders' pedagogical leadership from the lens of virtue ethics.

Keywords: education quality, institution leaders, virtue ethics, pedagogical leadership, vocational education and training.

\section{Introduction}

Education policy makers in Europe and around the world are increasingly aware of the global challenges society is facing in the $21^{\text {st }}$ century, such as tackling environmental issues, reducing corruption, terrorism, social inequalities and increasing employment opportunities (Glenn, et al., 2009). The awareness of the importance of moral agency for addressing these issues, and of the insufficiency of a competence-based educational approach without a strong ethical background, is growing (e.g., Attfield, 2015; Shaw \& Barry, 2015; O’Byrne, 2017).

Another topical concern for education policy makers and educators worldwide is the effectiveness and quality of education. Many external and internal factors contribute to the quality of educational institutions. Recent studies (Taipale, 2012; Fernández González \& Seņkāne, 2015; Çoğaltay \& Karadă̆, 2016; Jäppinen \& Ciussi, 2016; Mårtensson \& Roxå, 2016; Smith, et al., 2017) indicate that quality and effectiveness of education can be partially attributed to the educational leadership practices. Therefore, a research on educational leadership as one of the crucial aspects of the educational process provides an important background for improving this process at all levels of education system. However, the role of pedagogical leadership has changed the last few years, shifting its focus from teaching and learning to professional development (Butt, 2017). Integrated leadership, combining instructional and distributed leadership, 
is an important precondition for creating and sustaining professional learning communities (OECD, 2016a). Many scholars had also stressed the importance of educational leaders' personal qualities and character for ensuring quality of education (e.g., Gurr, 2015; The University of Nottingham, 2015; Butt, 2017). As an example, a recent study (Day \& Gurr, 2011), after a world-wide review of successful school leadership, highlighted the central role of institution leaders' personal qualities and dispositions (such as commitment, resilience, motivation over time, giving priority to establishing good relations), working hard (including courage, commitment and energy), and leaders' beliefs and values (including basic human values as well as moral, professional and social and political values) for leading schools successfully.

Empowering all people of working age to participate in economic and social life through accessible and equitable training opportunities is crucial (European Commission, 2010, p. 3). For vocational education and training (VET) providers, institutional leadership, which shows strategic direction and support collaborative environment for all staff, as well as career development opportunities, is a pivotal condition of success (European Commission, 2012, p. 38). VET provider's quality is built on two key factors, namely good leadership and management. Effective leadership creates a positive organizational culture that values trust, where people are motivated to ask questions, debate issues and contribute to each other's ongoing learning and inquiry (EQAVET, n.d., p. 27).

Latvia, according to recent reports elaborated by CEDEFOP (2015) and OECD (2016b), faces the challenge of improving VET quality and relevance, in order to adequately prepare young people for work, developing adult skills and responding to the needs of the labour-market (OECD, 2016b). Many efforts had been done this direction (The Cabinet of Ministers, 2009; Saeima, 2014; CEDEFOP, 2015; Fernández González, 2015; EQAVET, 2016). In April 2015, the Latvian Parliament (Saeima) adopted amendments to the Vocational Education Law, to ensure a better fit between VET and labour market needs at sectoral, institutional and programme levels (EQAVET, 2016). A new work-based learning model has also been recently initiated (The Ministry of Education and Science, 2014; Fernández González, 2015). Latvian government established sectoral expert councils and collegial advisory bodies (convents) at each VET institution, and created competence centres of vocational education for enhancing synergy between innovationoriented enterprises and scientific institutions in certain sectors (EQAVET, 2016; Latvian Investment and Development Agency, n.d.). In January 2017, a national assessment of all educational institutions leaders (including VET institutions) was launched by the Ministry of Education and Science of the Republic of Latvia (The Cabinet of Ministers, 2016), using international 
quality indicators (EQAVET) and including provisions for implementation of OECD recommendations.

Academics all around the world had addressed this important issue of general education school principalship and leadership (Mulford, 2003; Taipale, 2012; The University of Nottingham, 2015; Gurr, 2015; OECD, 2016a; Uljens, et al, 2016; Butt, 2017, etc.). Successful principals have core sets of deeply held values and moral and ethical purposes, and immense amounts of emotional understandings of themselves and others; are deeply respected and trusted by the communities which they serve; display high expectations and hopefulness in themselves and others; are values led; and perform well in areas such as curiosity, creativity, citizenship, and spirituality (The University of Nottingham, 2015; Gurr, 2015). A principal as a pedagogical leader should be a broad-minded communicator, inspirator, facilitator, and risk-taker, showing enthusiasm, integrity, truthfulness, insightfulness and positive thinking (Butt, 2017).

In the academic field, between 2000 and 2015 several $\mathrm{PhD}$ Theses in the field of school leadership and education management had been defended in Latvia, but this research is fragmentary and does not embrace all aspects of the field (Bluma \& Daiktere, 2016). According to Bluma and Daiktere (2016), after the recovering of the independence of Latvia, one of the first dissertations on education management (Ozola, 2002) discussed the theory of the management of a school and the characteristics of the school principal comparing practices in various countries, and stressed that the school principal should be at the same time a pedagogical leader and an organizer of the work of the school. Celma's dissertation (2004) deals with school principal's role during transition from Soviet education system to democratic school. Another dissertation (Upenieks, 2008) focused on criteria of becoming a school principal, which were based on formal and technical abilities rather than on personal competence. Daiktere's PhD thesis (2012) explores school principals' daily work, and how they influence the formation of the school culture, balancing a personal active role with participative leadership. Their supporting role for enhancing teachers' motivation and improving school culture is also addressed. Kalvans (2012), based on OECD PISA 2006 study, demonstrated the importance of principal's ability to facilitate teachers' professional development and motivation for education quality and the improvement of the learning environment and school microclimate, and provided recommendations for the assessment of quality of the principals' work.

However, till now, there are no academic studies addressing with a modern research methodology the pedagogical leadership of VET institutions in the context of Latvia as a democratic country. Considering the topicality of vocational education and training in the Latvian context, 
and the importance of pedagogical leadership dimensions and educational institution leaders' personality for quality education, it was decided to conduct a mixed method study seeking to highlight the associations between leadership dimensions and character features of pedagogical leaders of VET institutions that are recognized as providing high quality education in Latvia.

\section{Theoretical background}

Two different theoretical backgrounds were used for this study, one regarding virtues and another - leadership dimensions. The "Framework for Character Education" of the Jubilee Centre for Character and Virtues (JCCV) of the University of Birmingham (JCCV, 2017) was used as theoretical background for the analysis of leaders' virtues. The JCCV has largely used this framework for research on character strengths of student and experienced professionals in the fields of teaching, law, medicine, nursing, business and army, but there is not still a research focused on VET school principals using this framework.

The framework includes some prototypical moral virtues recognised and embraced by representatives of most cultures and religions around the world, such as courage (acting with bravery in fearful situations), justice (acting with fairness towards others by honouring rights and responsibilities), honesty (being truthful and sincere), compassion (exhibiting care and concern for others) and gratitude (feeling and expressing thanks for benefits). It includes also specific civic virtues, such as civility, service, citizenship, and volunteering, which regard the person's relations and responsibilities in society. Furthermore, the framework includes the intellectual virtues, which guide the quest for knowledge and information (e.g., curiosity, autonomy, critical thinking, judgement, reasoning, reflection, resourcefulness). This framework addresses also the personal traits that enable the person to manage his/her live effectively under the denomination of performance virtues, including resilience, determination, confidence and teamwork ability.

Gento's model of pedagogical leadership (Gento, 2002) was used as theoretical background for addressing leadership dimensions. This model was designed to be applied in educational institutions and tested with professionals of the educational field. It has been improved continuously since its first version appeared in 1996, contrasting theoretical reflection with the work of professionals and practitioners. According to this conception, educational leadership is characterized by the following eight dimensions: charismatic (attractiveness, trust-inspiring and natural authority), emotional (kindness and consideration of others), anticipatory 
(strategic vision and future-oriented thinking), professional (goal-orientation and competence), participatory (distributive leadership and collaborative style), cultural (identification with institutional culture), formative (promotion of professional development), and administrative (proficiency in bureaucratic and organizational work) (Gento \& González, 2012).

In this paper the authors were particularly interested in highlighting the association of leadership dimensions with positive references to leaders' personality. Based on this theoretical background, four research questions guided our research: a descriptive question about the most salient pedagogical leadership dimensions: an associational question, addressing implicit linkages between leadership dimensions and positive references to VET institutions' leaders' virtues; and two difference questions, for gaining a deeper understanding of group differences regarding opinions on leadership dimensions and their association with leaders' virtues. The questions were formulated as follows:

RQ1: What are the most salient pedagogical leadership dimensions of three

Latvian VET institutions' leaders according to the importance given to and the evidence found of them?

RQ2: What are the differences between students' and staff's opinions about the leaders of those institutions regarding the importance given to and the evidence found of the different pedagogical leadership dimensions?

RQ3: Which leadership dimensions and positive virtues of VET institutions' leaders are more often associated in respondents' discourse?

RQ4: What are the differences between respondents' groups regarding associations of positive virtues with leadership dimensions?

\section{Methodology}

The research was conducted applying a mixed-method approach. In the quantitative part of this study, data obtained in a previous study (2013) by the same research team using a face-to-face assisted web-based questionnaire ("Questionnaire on educational leadership in educational institutions" - 176 items) were used. The questionnaire was elaborated under the direction of Samuel Gento in 2002 (Gento, 2002) and updated in the Fall of 2012 by the research group "Pedagogical Leadership and Quality of Education" at Spain's university UNED, which also translated into English and piloted the questionnaire for usage in international studies such as the present one. The questionnaire addresses the eight dimensions of educational leadership and contains 80 indicators (ten features or characteristics for each leadership dimension).

In the qualitative part of the study, for ethical reasons, the authors decided to avoid asking directly VET teachers and students to make a 
personal evaluation of their VET institution leaders' personality. It was decided to use semi-structured interviews from the same previous study as secondary data for obtaining the necessary information about the features of the character of the pedagogical leaders. The interview guidelines, that were provided in the aforementioned reference frame (Gento, 2002), addressed institution leaders' strengths and weaknesses regarding the leadership dimensions ('charismatic', 'emotional', 'anticipatory' etc.). This approach was less intrusive: respondents spoke freely about their educational leader and, while speaking about how their leaders embodied the different dimensions of leadership, they revealed indirectly the personality characteristics they perceive behind the observed leaders' behaviours. Secondary analysis of these interviews through the lens of virtues provided a rich picture of leaders' personality characteristics.

\section{Participant institutions and data selection}

Two criteria were retained for the choice of the institutions whose primary data were used in this study: recognized excellence in their field, and a profile as different as possible for enriching the perspective of the study. The retained data were collected in three high-quality VET institutions located in Riga. The institution A focussed on tourism and food production, the institution $\mathrm{B}$ worked in the field of maritime education, and the institution $\mathrm{C}$ in the field of sport pedagogy. The time span between primary data collection and its secondary analysis in this study was relatively short (4 years).

In this research, the following primary data (questionnaires and interviews) were used for secondary analysis with a new research focus:

- 83 face-to-face assisted web-based questionnaires: 45 questionnaires from the institution A, 10 from the institution $\mathrm{B}$, and 28 from the institution C. $16 \%$ of the respondents were members of staff $(N=13)$, the rest were students $(N=70 ; 84 \%) .75 \%$ of the respondents were females $(N=62)$.

- 17 interviews: 6 with leading staff, 5 with teachers and 6 with students. 6 interviews were conducted at the institution A (2 students, 2 teachers and 2 members of the leading staff), 4 at the institution B ( 2 teachers and 2 members of the leading staff), and 7 at the institution C (4 students, 1 teacher, 2 members of the leading staff). The average duration was 12 minutes per interview.

All participants in the initial study were informed about anonymization, confidentiality and data protection policy, and they gave informed consent for audio or video recording and data usage for the research. 


\section{Data processing and analysis}

Quantitative data were processed and analysed by two researchers using software SPSS 22. A statistical analysis of quantitative data including both descriptive statistics and inferential statistics (Ho, 2006) was conducted. The descriptive statistics aimed primarily at describing the selected primary data and its major concern was to present information in a convenient, usable, and understandable form. The descriptive statistics were used to describe the data set in terms of frequency of occurrence, central tendency (mean, median, and mode), and dispersion (variances and standard deviations). The reliability and validity of the selected quantitative data set was checked conducting a reliability analysis. The value of Cronbach's Alpha was higher than 0.90 . Therefore, the data set was highly reliable. The Kolmogorov-Smirnov test was used for determining the type of distribution of the statistical data, which were not normally distributed. The non-parametrical Mann-Whitney Test was used for determining the differences between the two respondents' groups (staff and students).

According to Robson and McCartan (2016), in qualitative studies the research question should determine if manifest or latent content analysis should be used. For the reasons explained before, latent content analysis (Neuendorff, 2016) was used in this research for analysing the interviews. A code system based on the JCCV framework (four main codes referring to the four kinds of virtue of the framework, and child-codes corresponding to specific virtues) was adapted for this research and uploaded in a shared Google document for allowing real-time updates of the code list during the coding process. Three coding modes were used for each virtue: positive mode (the virtue is praised), negative mode (respondents complain that the opposite vice is shown in leaders' behaviour) or desirable mode (the respondents stated that it would be desirable that the leader shows a concrete virtue).

Three researchers coded the interviews using AQUAD 7 software (Huber \& Gürtler, 2013), either directly on the audio file or transcribing the interviews. In order to ensure a shared understanding of code content and intercoder reliability, at the beginning of the coding process, researchers coded in pairs two different files. The leading researcher participated in both pairs for unifying the understandings of codes. This step was important because latent content analysis demands a relative high level of inference or interpretation on the part of the coder (Robson \& McCartan, 2016). After that, each researcher worked individually on the interviews of the institution allocated to him or her, coding them and analysing the data with software AQUAD 7 according to a common procedure: if, when answering a question about one of the eight leadership dimensions, 
a respondent mentioned a virtue of the leader, an implicit association between this virtue and this dimension was recorded. Once all files were coded and analysed, the obtained data were assembled in a single Excel file for joint frequency and linkage analysis.

\section{Results}

The presentation of the results was structured according to the research questions. The results regarding the first research question - RQ1 [What are the most salient pedagogical leadership dimensions of three Latvian VET institutions' leaders according to the importance given to and the evidence found of them?] are presented in Table 1 (commented figures highlighted in bold).

Table 1. Importance and evidence of leadership dimensions (Means in a 9-point scale)

\begin{tabular}{|c|c|c|}
\hline Dimension & $\begin{array}{c}\text { Importance } \\
\text { (Mean) }\end{array}$ & $\begin{array}{c}\text { Evidence } \\
\text { (Mean) }\end{array}$ \\
\hline Charismatic & 7.73 & 7.10 \\
\hline Emotional & 7.55 & 7.14 \\
\hline Anticipatory & 7.45 & 7.04 \\
\hline Professional & 7.77 & 7.33 \\
\hline Participatory & 7.37 & 7.00 \\
\hline Cultural & 7.12 & 6.38 \\
\hline Formative & 7.20 & 6.87 \\
\hline Administrative & 7.46 & 7.12 \\
\hline General Mean & 7.46 & 7.00 \\
\hline
\end{tabular}

According to the results of descriptive statistics, the most important dimensions were 'professional' (Mean = 7.77), 'charismatic' (Mean = 7.73), and 'emotional' (Mean $=7.55$ ), and the most evident dimensions were 'professional' (Mean $=7.33$ ), 'emotional' (Mean $=7.14$ ), and 'administrative' (Mean = 7.12). 'Professional' and 'emotional' dimensions were the most salient both in important and evidence. The 'charismatic' dimension was salient in importance and also was rated over the average in evidence.

The results regarding the second research question - RQ2 [What are the differences between students' and staff's opinions about the leaders of those institutions regarding the importance given to and the evidence found of the different pedagogical leadership dimensions?] are presented in Table 2. 
Table 2. Importance and evidence of dimensions (mean rank by the Mann-Whitney test)

\begin{tabular}{l|c|c|r|r|r|r|r}
\hline \multirow{2}{*}{ Dimension } & \multicolumn{3}{|c|}{$\begin{array}{c}\text { Importance by } \\
\text { mean rank }\end{array}$} & \multicolumn{3}{c|}{$\begin{array}{c}\text { Evidence by } \\
\text { mean rank }\end{array}$} & $\begin{array}{c}\text { Sum- } \\
\text { mated } \\
\text { differ- } \\
\text { ence }\end{array}$ \\
\cline { 2 - 8 } & $\begin{array}{c}\text { stu- } \\
\text { dents }\end{array}$ & staff & $\begin{array}{r}\text { differ- } \\
\text { ence }\end{array}$ & $\begin{array}{c}\text { stu- } \\
\text { dents }\end{array}$ & staff & $\begin{array}{r}\text { differ- } \\
\text { ence }\end{array}$ \\
\hline Charismatic & $\mathbf{4 2 . 7 0}$ & 38.23 & 4.47 & $\mathbf{4 2 . 6 6}$ & 38.42 & 4.24 & 8.71 \\
\hline Emotional & $\mathbf{4 2 . 7 2}$ & 38.12 & 4.60 & $\mathbf{4 2 . 5 8}$ & 38.88 & 3.70 & 8.30 \\
\hline Anticipatory & 41.18 & $\mathbf{4 6 . 4 2}$ & -5.24 & 41.39 & $\mathbf{4 5 . 2 7}$ & -3.88 & -9.12 \\
\hline Professional & 39.72 & $\mathbf{5 4 . 2 7}$ & -14.55 & 41.05 & $\mathbf{4 7 . 1 2}$ & -6.07 & -20.62 \\
\hline Participatory & 39.56 & $\mathbf{5 5 . 1 2}$ & -15.56 & 40.98 & $\mathbf{4 7 . 5 0}$ & -6.52 & $\mathbf{- 2 2 . 0 8}$ \\
\hline Cultural & 38.84 & $\mathbf{5 5 . 6 2}$ & -16.78 & 39.88 & $\mathbf{5 0 . 0 8}$ & -10.20 & $\mathbf{- 2 6 . 9 8}$ \\
\hline Formative & 40.02 & $\mathbf{5 2 . 6 5}$ & -12.63 & 40.30 & $\mathbf{4 1 . 5 4}$ & -1.24 & -13.87 \\
\hline Administrative & 41.04 & $\mathbf{4 7 . 1 5}$ & -6.11 & 39.96 & $\mathbf{5 3 . 0 0}$ & -13.04 & -19.15 \\
\hline
\end{tabular}

In general, the students rated higher on importance and evidence of 'charismatic' and 'emotional' dimensions, but the staff (the institution leaders and teachers) rated higher on importance and evidence of all other dimensions. Using the Mann-Whitney Test, statistically significant differences were found between both groups regarding the importance given the 'professional' $(p=.036)$, 'participatory' $(p=.026)$ and 'cultural' dimensions $(p=.015)$. These differences will be addressed in the discussion.

The results regarding the third research question - RQ3 [Which leadership dimensions and positive virtues of VET institutions' leaders are more often associated in respondents' discourse?] are presented in Table 3.

107 associations were found between leadership dimensions and virtues mentioned in a positive mode. Overall, respondents mentioned most often leaders' positive virtues when speaking about the following leadership dimensions: 'emotional' (20 linkages), 'formative' (18), 'anticipatory' (17), and 'charismatic' (15). Although the most salient leadership dimension was the 'professional' one (see Table 1), the number of references to leaders' virtues associated to it is relatively low $(N=11)$. Almost half of the positive virtues mentioned by respondents referred to performance virtues $(N=46$, $45 \%)$, which was particularly associated with the 'participatory' dimension (67\% of the associations within 'participatory' dimension) and the 'cultural' dimension ( $56 \%$ of the association within 'cultural' dimension). A quart of the virtues mentioned were intellectual virtues $(N=28,24 \%)$, and moral and civic virtues account for $15-16 \%$. 
Table 3. Association between leadership dimensions and praised virtues (by type of virtue)

\begin{tabular}{|c|c|c|c|c|c|c|c|c|c|c|c|}
\hline \multirow[b]{2}{*}{$\begin{array}{l}\text { Type of } \\
\text { virtues }\end{array}$} & & \multicolumn{10}{|c|}{ Leadership dimensions } \\
\hline & & 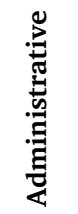 & 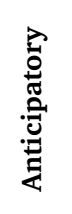 & 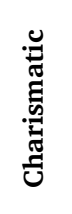 & 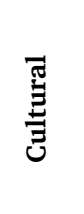 & 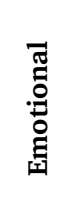 & 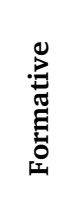 & 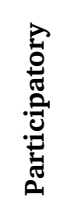 & 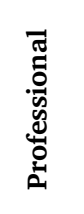 & సٓํํ & \\
\hline \multirow{3}{*}{$\begin{array}{l}\text { Civic } \\
\text { virtues }\end{array}$} & count & 1 & 5 & 7 & 1 & 3 & 1 & 0 & 1 & 19 & \\
\hline & $\begin{array}{l}\text { \%within } \\
\text { virtues }\end{array}$ & $5 \%$ & $26 \%$ & $37 \%$ & $5 \%$ & $16 \%$ & $5 \%$ & $0 \%$ & $5 \%$ & $\begin{array}{c}100 \\
\%\end{array}$ & $\begin{array}{c}\text { total } \\
\%\end{array}$ \\
\hline & $\begin{array}{l}\text { \%within } \\
\text { dimensions }\end{array}$ & $13 \%$ & $29 \%$ & $47 \%$ & $11 \%$ & $15 \%$ & $6 \%$ & $0 \%$ & $9 \%$ & $16 \%$ & $\begin{array}{c}\text { mean } \\
\%\end{array}$ \\
\hline \multirow{3}{*}{$\begin{array}{l}\text { Intellectu- } \\
\text { al virtues }\end{array}$} & count & 1 & 2 & 2 & 2 & 8 & 8 & 1 & 4 & 28 & \\
\hline & $\begin{array}{l}\text { \%within } \\
\text { virtues }\end{array}$ & $4 \%$ & $7 \%$ & $7 \%$ & $7 \%$ & $29 \%$ & $29 \%$ & $4 \%$ & $14 \%$ & $\begin{array}{c}100 \\
\%\end{array}$ & $\begin{array}{c}\text { total } \\
\%\end{array}$ \\
\hline & $\begin{array}{l}\text { \%within } \\
\text { dimensions }\end{array}$ & $13 \%$ & $12 \%$ & $13 \%$ & $22 \%$ & $40 \%$ & $44 \%$ & $11 \%$ & $36 \%$ & $24 \%$ & $\begin{array}{c}\text { mean } \\
\%\end{array}$ \\
\hline \multirow{3}{*}{$\begin{array}{l}\text { Moral } \\
\text { virtues }\end{array}$} & count & 2 & 3 & 0 & 1 & 2 & 1 & 2 & 3 & 14 & \\
\hline & $\begin{array}{l}\text { \%within } \\
\text { virtues }\end{array}$ & $14 \%$ & $21 \%$ & $0 \%$ & $7 \%$ & $14 \%$ & $7 \%$ & $14 \%$ & $21 \%$ & $\begin{array}{c}100 \\
\%\end{array}$ & $\begin{array}{c}\text { total } \\
\%\end{array}$ \\
\hline & $\begin{array}{l}\text { \%within } \\
\text { dimensions }\end{array}$ & $25 \%$ & $18 \%$ & $0 \%$ & $11 \%$ & $10 \%$ & $6 \%$ & $22 \%$ & $27 \%$ & $15 \%$ & $\begin{array}{c}\text { mean } \\
\%\end{array}$ \\
\hline \multirow{3}{*}{$\begin{array}{l}\text { Perfor- } \\
\text { mance } \\
\text { virtues }\end{array}$} & count & 4 & 7 & 6 & 5 & 7 & 8 & 6 & 3 & 46 & \\
\hline & $\begin{array}{l}\text { \%within } \\
\text { virtues }\end{array}$ & $9 \%$ & $15 \%$ & $13 \%$ & $11 \%$ & $15 \%$ & $17 \%$ & $13 \%$ & $7 \%$ & $\begin{array}{c}100 \\
\%\end{array}$ & $\begin{array}{c}\text { total } \\
\%\end{array}$ \\
\hline & $\begin{array}{l}\text { \%within } \\
\text { dimensions }\end{array}$ & $50 \%$ & $41 \%$ & $40 \%$ & $56 \%$ & $35 \%$ & $44 \%$ & $67 \%$ & $27 \%$ & $45 \%$ & $\begin{array}{c}\text { mean } \\
\%\end{array}$ \\
\hline \multirow[t]{3}{*}{ Total } & count & 8 & 17 & 15 & 9 & 20 & 18 & 9 & 11 & 107 & \\
\hline & $\begin{array}{l}\text { \%within } \\
\text { virtues }\end{array}$ & $8 \%$ & $18 \%$ & $14 \%$ & $8 \%$ & $18 \%$ & $15 \%$ & $8 \%$ & $12 \%$ & $\begin{array}{c}100 \\
\%\end{array}$ & $\begin{array}{c}\text { total } \\
\%\end{array}$ \\
\hline & $\begin{array}{l}\text { \%within } \\
\text { dimensions }\end{array}$ & $\begin{array}{c}100 \\
\%\end{array}$ & $\begin{array}{c}100 \\
\%\end{array}$ & $\begin{array}{c}100 \\
\%\end{array}$ & $\begin{array}{c}100 \\
\%\end{array}$ & $\begin{array}{c}100 \\
\%\end{array}$ & $\begin{array}{c}100 \\
\%\end{array}$ & $\begin{array}{c}100 \\
\%\end{array}$ & $\begin{array}{c}100 \\
\%\end{array}$ & $\begin{array}{c}100 \\
\%\end{array}$ & $\begin{array}{c}\text { mean } \\
\%\end{array}$ \\
\hline
\end{tabular}

The strongest association was found between civic virtues and the 'charismatic' dimension of leadership: $47 \%$ of the virtues recorded within this 'charismatic' dimension are civic virtues, and more than $1 / 3$ of all civic virtues (37\%) were associated with 'charismatic' dimension. Slightly 
lower bet still high associations were found between intellectual virtues and two leadership dimensions: the 'formative' and 'emotional' ones: $58 \%$ of all intellectual virtues were associated with the 'emotional' or 'formative' dimension in equal proportion ( $29 \%$ each); and $44 \%$ of the virtues associated with the 'formative' dimension were intellectual virtues (the figure for the 'emotional' dimension is $40 \%$ ).

Summarizing the findings about the RQ3 strong associations were found between leaders' civic virtues and 'charismatic' dimension, and between intellectual virtues and the 'formative' and 'emotional' dimensions. These associations will be discussed latter.

The results regarding the fourth research question - RQ4 [What are the differences between respondents' groups regarding associations of positive virtues with leadership dimensions?] are presented in Table 4.

Out of the 107 associations of positive virtues with leadership dimensions, the highest rate of linkages was found within leading staff $(N=44,41 \%)$, and the lowest - within students $(N=26,24 \%)$. Across leadership dimensions, the highest number of association was found within 'emotional' dimension $(N=20,19 \%)$.

Leading staff most often praised leaders' virtues when speaking about 'emotional' and 'formative' dimensions (11 linkages each) and 'anticipatory' dimension (9 linkages). Students praised leaders' virtues when reflecting on the 'charismatic' dimension (8 linkages) and 'professional' dimension (5 linkages). Teachers reported most of leaders' virtues when reflecting on the 'emotional' dimension (8 linkages). They are the group that praised leaders' virtues most often in relation with the 'cultural' dimension of the institution (5 linkages).

Table 4. Frequency of linkages of virtues (positive mode) with leadership dimensions by respondents' group

\begin{tabular}{lccccc}
\hline \multirow{2}{*}{ Leadership dimension } & \multicolumn{3}{c}{ Respondents' group } & \multirow{2}{*}{ Total } & \multirow{2}{*}{$\%$} \\
\cline { 2 - 5 } & Leading staff & Student & Teacher & & \\
\hline Administrative & 3 & 1 & 4 & 8 & $7 \%$ \\
Anticipatory & $\mathbf{9}$ & 4 & 4 & 17 & $16 \%$ \\
Charismatic & 2 & $\mathbf{8}$ & 5 & 15 & $14 \%$ \\
Cultural & 3 & 1 & $\mathbf{5}$ & 9 & $8 \%$ \\
Emotional & $\mathbf{1 1}$ & 1 & $\mathbf{8}$ & 20 & $19 \%$ \\
Formative & $\mathbf{1 1}$ & 2 & 5 & 18 & $17 \%$ \\
Participatory & 3 & 4 & 2 & 9 & $8 \%$ \\
Professional & 2 & $\mathbf{5}$ & 4 & 11 & $10 \%$ \\
Total (\%) & $44(41 \%)$ & $26(24 \%)$ & $37(35 \%)$ & 107 & $100 \%$ \\
\hline
\end{tabular}


Summarizing the findings about the RQ4, leading staff has the highest number of positive virtues linked to leadership dimensions, and respondents most often praised leaders' virtues when speaking about 'emotional' and 'formative' dimension. Students have the lowest number of associations, which appeared mostly around the 'charismatic' dimension; most of the teachers' mentioned virtues were associated with the 'emotional' dimension.

\section{Discussion}

The focus of this discussion is the associations between leadership dimensions and virtues (RQ3), and the differences among groups (RQ4). The quantitative results of the study were used in the discussion when it was necessary for gaining deeper understanding about a concrete leadership dimension (RQ1) or about group specificities (RQ2). In the Figure 1, the main associations of leadership dimensions with the different kind of virtues and with respondent groups' activity mentioning virtues are visualized.

As it can be seen (see Figure 1), students seemed to adopt a position different from leading staff and teachers. They praised most of VET institution leaders' virtues when speaking about the 'charismatic' dimension of leadership, which is strongly associated with civic virtues. On the other hand, both leading staff and teachers were very active recalling leaders' virtues when speaking about the 'emotional' dimension of leadership and, for the leading staff, when speaking about the 'formative' dimension also. Both 'formative' and 'emotional' dimensions were strongly associated with intellectual virtues. We discussed below these differences more in detail.

As regards the association between VET institution leaders' positive virtues and leadership dimensions (RQ3), conceptually it was expected that

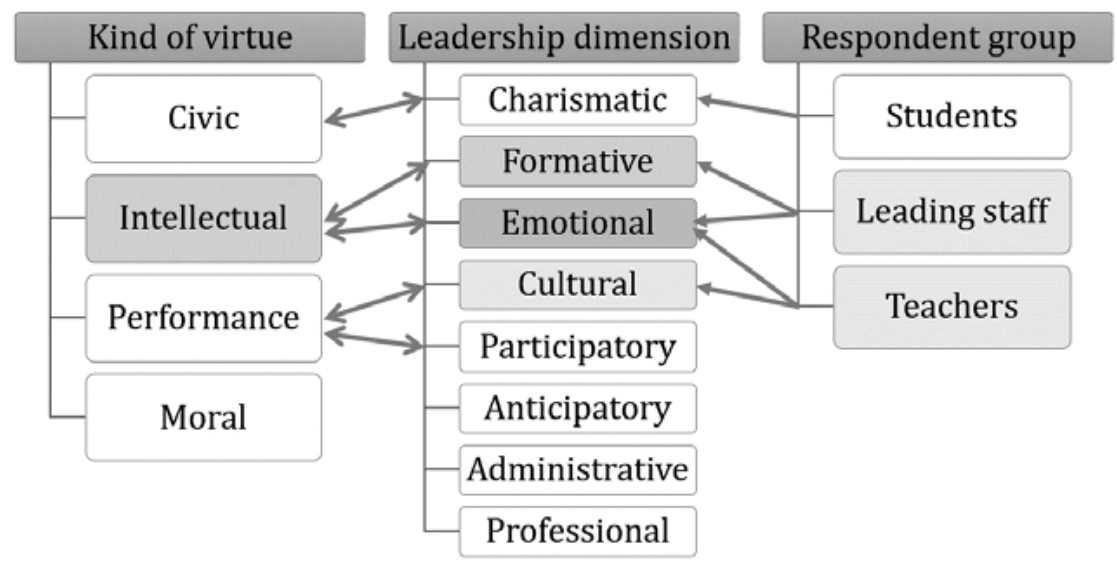

Figure 1. Leadership dimensions association with kind of virtues and respondent groups' activity 
civic virtues will be associated with 'participatory' and 'cultural' dimensions of leadership, which both demand the participative attitudes, civility and service included in the civic virtues. But instead, an unexpected strong association between leaders' civic virtues and the 'charismatic' dimension of leadership was found. This association may mean that, for participants, charismatic (attractive) leaders are the ones who are able to show in practice civic attitudes such as neighbourliness, community awareness and service. These results are coherent with the recent study regarding features of the character of VET institutions' pedagogical leaders (Fernández González, et al., in press), in which it was found that respondents showed higher concern and sensitivity about VET leaders' civic virtues (encouraging others, community awareness, teamwork ability).

It could be also expected that respondents will refer to leaders' intellectual virtues mostly when speaking about 'anticipatory' and 'formative' leadership dimensions, which demand far-sighting, critical thinking and judgement that intellectual virtues facilitate. The association with the 'formative' dimension was found in the data, but an unexpected strong association between intellectual virtues and the 'emotional' dimension of leadership was also revealed. This association may mean that, for participants, emotionally competent leaders (those who made people feel well, comfortable, secure and protected), are the ones who are perceived as having intellectual virtues (critical thinking, reflectivity, judgement and resourcefulness) that allows them to lead the institution smartly and efficiently.

These unexpected associations with 'charismatic' and 'emotional' dimensions were explored in-depth, looking at the results of the quantitative part of the study (see Table 1). 'Emotional' and 'charismatic' dimensions were highly-rated among the 8 leadership dimensions. After the 'professional' dimension, which was the highest rated both in importance and evidence, the 'emotional' dimension got the $2^{\text {nd }}$ rank in evidence and the $3^{\text {rd }}$ in importance; and the 'charismatic' dimension $-2^{\text {nd }}$ rank in importance and $4^{\text {th }}$ in evidence; both dimensions were rated higher than the average in importance and evidence. Conceptually, it could be expected that these two significant leadership dimensions would be associated with leaders' moral virtues (courage, justice, fairness, honesty and compassion), but instead, respondents linked them with civic virtues and intellectual virtues respectively. Respondents did not praise spontaneously their leaders' moral virtues when referring to 'charismatic' and 'emotional' dimensions, and they also rarely mentioned moral virtues in a positive mode, but they did it more often in desirable mode. This finding could be discussed in the light of recent literature stressing the relevance of the moral dimension of pedagogical leaders presented in the introduction (Day \& Gurr, 2011; Gurr, 2015; Butt, 
2017, etc.). This could mean that, in Latvian context, the perceived leaders' efficiency and civic behaviour are appreciated higher that their inner moral qualities, but more research is needed to confirm this hypothesis.

Conceptually, it could be expected that performance virtues will be associated with the 'professional' and 'administrative' dimension of leadership, in which performance virtues (such as resilience, determination and teamwork) would be most useful. Instead, unexpected strong associations of performance virtues with 'participatory' and 'cultural' dimensions were found (respectively, $67 \%$ and $56 \%$ of the associations within those dimensions). This means that, in general, respondents praised leaders' performance virtues when thinking about participation in school work and about the identity of their school. It is interesting to note that, in the quantitative analysis, the largest statistically significant differences between students and staff were found precisely in these two dimensions - 'participatory' and 'cultural' (see Table 2). It seems that institutional culture and participation are important aspects of leadership for school staff, but students rated their importance and evidence much lower.

When looking at the differences between respondent groups regarding the way they associate leaders' virtues with leadership dimensions (RQ4), it was assumed that each group of respondents was willing to highlight leaders' virtues when they were asked about those leadership dimensions that were more personally significant for them. Students praised VET institutional leaders' virtues mostly in relation with the 'charismatic' dimension of leadership, which is strongly related to civic virtues in our data. The personal significance of leaders' charisma for students was confirmed by the quantitative data (RQ2), which show that students rated higher than staff the importance and evidence of the 'charismatic' dimension (see Table 2). This seems to indicate that students appreciate particularly leaders' charismatic and attractive personality and his/her civic virtues, such as neighbourliness, community awareness and service, but more research is needed to confirm these findings at a larger scale.

Leading staff mentioned VET institution leaders' positive virtues in relation with the 'emotional' and 'formative' dimensions of leadership. According to the mentioned assumptions, this would mean that VET institution leaders were particularly concerned about students' and teachers' 'emotional' and 'formative' (professional development) needs. This association of the 'emotional' dimension with professional development, which is related to the intellectual virtues necessary for enhancing professional competence, is coherent with the association of intellectual virtues with the 'emotional' dimension of leadership discussed previously in this section of the paper. Teachers, like leading staff, were quite active when speaking about the 'emotional' dimension of leadership, which could indicate their concern 
about both their own and students' wellbeing. In their case, this emotional concern is not associated with the professional development ('formative' leadership dimension), but with the 'cultural' dimension of leadership (enhancing a sense of belonging). This is another remarkable difference with students, who rated the importance and evidence of the 'cultural' dimension much lower than staff in the quantitative study (see Table 2). More research would be necessary to explain these differences.

\section{Conclusion}

In this study, the most salient pedagogical leadership dimensions and their relationship with character features of the heads of three remarkable VET institutions in Latvia were explored, using quantitative analysis of questionnaire data and latent content analysis of interviews with students, teachers and staff.

The most salient leadership dimensions were the 'professional', 'charismatic' and 'emotional' ones. School staff rated the importance of 'professional', 'participatory' and 'cultural' dimensions statistically significantly higher than students. The following unexpected associations between VET leaders' virtues and leadership dimensions were found: between leaders' civic virtues and the 'charismatic' dimension of leadership (indicating that attractive leaders are the ones who are able to show civic attitudes); between intellectual virtues and the 'emotional' dimension of leadership (indicating that respondents feel emotionally satisfied when the institution is leaded smartly and efficiently); and between performance virtues and the 'participatory' and 'cultural' dimensions. Other group differences were that students praised VET leaders' virtues mostly while speaking about the 'charismatic' dimension of leadership, while leading staff and teachers did so while speaking about 'emotional' dimension. Leading staff also linked leaders' virtues with the 'formative' dimension of leadership, while teachers linked it more often with the 'cultural' dimension.

These results offer an original picture of the specific features of character of these exemplar institution leaders, who were able to combine personal charisma with civic attitudes and neighbourliness, and to create an emotionally rewarding institutional atmosphere, using their personal acumen and good sense for leading the institution successfully.

Compared with former research (Gento \& González, 2012) this study represents an innovative methodological contribution for investigating educational institution leaders' pedagogical leadership from the lens of virtue ethics. The use of a virtue framework for data analysis provided an ethically correct enriching perspective, and deep insights into VET leaders' personality. 
The limitations of the study are inherent to the qualitative methodology adopted. It may be useful to complete this approach with a quantitative study addressing the relation between leadership dimensions and leaders' virtues. It could be also interesting to compare the results of this study with similar ones in different geographical and cultural contexts.

\section{Acknowledgements}

Research financed by the European Regional Development Fund within the post-doctoral project (number 1.1.1.2/VIAA/1/16/071) and by the University of Latvia within the research project "Human, technologies and quality of education" (2016-2018) conducted at the Faculty of Education, Psychology and Art.

\section{References}

Attfield, R. (2015). Ethics of the Global Environment. Edinburgh: Edinburgh University Press.

Bluma, D., \& Daiktere, I. (2016). Latvia: School Principals and Leadership Research in Latvia. In: Ärlestig, H., Day, C., \& Johansson, O. (Eds.) A Decade of Research on School Principals: Cases from 24 Countries, vol. 21, 137-160. Springer, Cham. DOI: 10.1007/978-3-319-23027-6_8.

Butt, M. I. (2017). Principal, as a pedagogical leader: in the perspective of good governance in the public-sector colleges of Pakistan. Proceedings of $59^{\text {th }}$ ISERD International Conference, Sydney, Australia, $4^{\text {th }}-5^{\text {th }}$ January 2017, pp. 24-27.

CEDEFOP. (2015). Vocational education and training in Latvia: Short description. Luxembourg: Publications Office of the European Union. CEDEFOP information series.

Celma, D. (2004). Direktora loma pašpārvaldošas skolas veidošanā (Principal's role in developing a self-managed school). Latvijas Universitātes Raksti, 675, 48-55.

Çoğaltay, N., \& Karadağ, E. (2016). The effect of educational leadership on organizational variables: a meta-analysis study in the sample of Turkey. Educational Sciences: Theory \& Practice, 16(2), 603-646. DOI: 10.12738/estp.2016.2.2519.

Daiktere, I. (2012). School heads 'role in the process of developing school culture of comprehensive educational institutions in Latvia. Dissertation. Riga: University of Latvia.

Day, C., \& Gurr, D. (2011). Leading Schools Successfully: Stories from the Field. Routledge, London.

EQAVET (2016). Results EQAVET Secretariat Survey 2016. Retrieved from https://www. eqavet.eu/Eqavet2017/media/Documents/Report-implementation-of-EQAVET-ResultsEQAVET-Secretariat-Survey-2016.pdf [accessed 28 August 2018].

EQAVET [n. d.]. VET providers' self-monitoring by using the EQAVET toolbox of indicators (A Guide for National Reference Points). Retrieved from https://www.eqavet.eu/ Eqavet2017/media/Documents/GUIDE-VET-providers-self-monitoring-by-using-theEQAVET-toolbox-of-indicators.pdf [accessed 28 August 2018]. 
European Commission (2010). Communication from the commission to the European Parliament, the Council, the European Economic and Social Committee and the committee of the regions. A new impetus for European cooperation in Vocational Education and Training to support the Europe 2020 strategy. Brussels, 9.6.2010 COM(2010) 296 final. Retrieved from http://eur-lex.europa.eu/legal-content/EN/TXT/PDF/?uri=CELEX:5201 0DC0296\&from $=$ EN [accessed 28 August 2018] .

European Commission (2012). Commission staff working document: Vocational education and training for better skills, growth and jobs. Accompanying the document. Communication from the Commission. Rethinking Education: Investing in skills for better socio-economic outcomes. Strasbourg, 20.11.2012 SWD(2012) 375 final. Retrieved from http://eur-lex.europa.eu/legal-content/EN/TXT/PDF/?uri = CELEX:5201 2SC0375\&from $=$ EN [accessed 28 August 2018].

Fernández González, M. J. (2015). Possibilities of bilateral collaboration between Latvia and Switzerland in the field of vocational education and training. Recommendations about the priority fields and modalities of implementation of future collaboration. Report. Riga: University of Latvia.

Fernández González, M. J., \& Seņkāne, L. (2015). Educational leadership in higher education: professionalism versus emotional satisfaction. A case study from Lavia. In: I. Margeviča-Grinberga, G. Krağe, M. J. Fernández González, \& I. Odina (Eds.), Improving the Quality of Thinking and Action in Higher Education; The Roles of Cognition and Emotion. Proceedings of the $3^{\text {rd }}$ International RIAICES Congress (pp. 76-93). Riga: University of Latvia.

Fernández González, M. J., Pīgozne, T., Surikova, S., \& Vasečko, L.. (in press). Pedagogical leaders' personality relevance for vocational education quality. Quality Assurance in Education.

Gento, S. (2002). Instituciones Educativas para la Calidad Total. Madrid: La Muralla.

Gento, S., \& González, R. (2012). Leadership and Quality in Today's Educational Institutions of European Countries. Paper presented at the XIII Workshop of Qualitative Research n Psychology "Building bridges". March $11^{\text {th }}$ to $14^{\text {th }} 2012$, Achva Academi College of Education, Israel. Retrieved from http://www.leadquaed.com/docs/artic\%20ing/ Leadership\%20and\%20quality.pdf [accessed 28 August 2018].

Glenn, J. C., Gordon, T. J., \& Florescu, E. (2009). The Millennium Project. 2007 State of the Future. Washington: The Millennium Project.

Gurr, D. (2015). A model of successful school leadership from the International Successful School Principalship Project, Societies, 5, 136-150. DOI:10.3390/soc5010136.

Ho, R. (2006). Handbook of Univariate and Multivariate Data Analysis and Interpretation with SPSS. Boca Raton: Chapman \& Hall/CRC, Taylor \& Francis Group.

Huber, G. L., \& Gürtler, L. (2013). AQUAD 7 Manual: The Analysis of Qualitative Data. Tübingen, Germany: Softwarevertrieb Günter Huber.

Jäppinen, A.-K., \& Ciussi, M. (2016). Indicators of improved learning contexts: a collaborative perspective on educational leadership. International Journal of Leadership in Education, 19(4), 482-504. DOI: 10.1080/13603124.2015.1015616

JCCV, Jubilee Center for Character and Virtues. (2017). A framework for character education in schools. Retrieved from http://www.jubileecentre.ac.uk/userfiles/jubileecentre/pdf/character-education/Framework\%20for\%20Character\%20Education.pdf [accessed 28 August 2018].

Kalvans, R. (2012). The role of school principal quality assurance in education. $\mathrm{PhD}$ thesis. Riga: University of Latvia. 
Latvian Investment and Development Agency [n. d.]. State support program "Competence Centres". Retrieved from http://www.liaa.gov.lv/files/liaa/attachments/ informacija_par_projektiem_kas_tiek_istenoti.pdf [accessed 28 August 2018].

Latvijas Republikas Izglìtības un zinātnes ministrija (The Ministry of Education and Science) (2014). Par darba vidē balstitu mācību istenošanas iespējām Latvijas profesionālās izglitibas attistibas kontekstā. Informativais zinnojums. Retrieved from http://www.mk.gov. $\mathrm{lv} / \mathrm{lv} / \mathrm{mk} / \mathrm{tap} /$ pid $=40319533 \&$ mode $=\mathrm{mk} \&$ date $=2014-08-12 \quad$ [accessed 28 August 2018].

Latvijas Republikas Ministru kabinets (The Cabinet of Ministers) (2009). Noteikumi Nr. 629. Par koncepciju "Profesionālās izglïtibas pievilcỉbas paaugstināšana un sociālo partneru lìdzdalïba profesionālās izglītibas kvalitātes nodrošināšanā" (Conceptual position about "Attractiveness in Vocational Education and Social Partners within Vocational Education Quality Assurance). Last modified: 17.08.2012. Retrieved from http://likumi. lv/doc.php?id = 197894 [accessed 28 August 2018].

Latvijas Republikas Ministru kabinets (The Cabinet of Ministers) (2016). Ministru kabineta 20.12.2016. noteikumi Nr. 831 "Kārtïba, kādā akreditē izglïtibas iestādes, eksaminācijas centrus un citas Izglītibas likumā noteiktās institūcijas, vispārējās un profesionālās izglīīibas programmas un novērtēe valsts augstskolu vidējās izglīības iestāžu, valsts un pašvaldību izglïtibas iestāžu vadītāju profesionālo darbïbu". Retrieved from https://likumi.lv/ta/ id/287602-kartiba-kada-akredite-izglitibas-iestades-eksaminacijas-centrus-un-citasizglitibas-likuma-noteiktas-institucijas [accessed 28 August 2018].

Mårtensson, K., \& Roxå, T. (2016). Leadership at a local level - enhancing educational development. Educational Management Administration \& Leadership, 44(2), 247-262. DOI: $10.1177 / 1741143214549977$.

Mulford, B. (2003). School leaders: Changing roles and impact on teacher and school effectiveness. A paper commissioned by the Education and Training Policy Division, OECD, for the Activity "Attracting, Developing and Retaining Effective Teachers". Retrieved from http://www.oecd.org/education/school/2635399.pdf [accessed 28 August 2018].

Neuendorf, K. A. (2016). The Content Analysis Guidebook. London: Sage.

O’Byrne, D. (2017). Global Ethics and Civil Society. London: Routledge.

OECD (2016a). School Leadership for Learning: Insights from TALIS 2013. Paris: TALIS, OECD Publishing.

OECD (2016b). Reviews of National Policies for Education: Education in Latvia. Paris: OECD Publishing.

Ozola, Z. (2002). Development of the structure and the management of the private schools. Dissertation. Rīga: Latvijas Universitāte.

Robson, C., \& McCartan, K. (2016). Real World Research. London: John Wiley \& Sons.

Saeima (2014). Statement about approval of education development guidelines for 2014-2020. Retrieved from http://likumi.lv/doc.php?id=266406 [accessed 28 August 2018].

Schulz, W., Ainley, J., Fraillon, J., Losito, B., Agrusti, G., \& Friedman, T. (2016). Becoming citizens in a changing world. IEA International Civic and Citizenship Education Study 2016 International Report. SpringerOpen. Retrieved from: http://iccs.iea.nl/ fileadmin/user_upload/Editor_Group/Downloads/ICCS_2016_International_report.pdf [accessed 28 August 2018].

Shaw, W. H., \& Barry, V. (2015). Moral Issues in Business. Boston, MA: Cengage Learning. 
Smith, D., Kelly, D., \& Allard, C. (2017). Dialogic spaces: a critical policy development perspective of educational leadership qualifications. International Journal of Leadership in Education, 20(4), 393-415. DOI: 10.1080/13603124.2015.1116608.

Taipale, A. (2012). International survey on educational leadership. A survey on school leader's work and continuing education. Finnish National Board of Education. Retrieved from https://www.oph.fi/download/143319_International_survey_on_educational_leadership.PDF [accessed 28 August 2018].

The University of Nottingham (2015). International Successful School Principals Project (ISSPP): Multi-perspective research on school principals. Retrieved from https://www. uv.uio.no/ils/english/research/projects/isspp/isspp-brochure-27_jul_final_amended.pdf [accessed 28 August 2018].

Uljens, M., Sundqvist, R., \& Smeds-Nylund, A.-S. (2016). Educational leadership for sustained multi-level school development in Finland - A non-affirmative approach. Nordic Studies in Education, 36(2), 103-124.

Upenieks, A. (2008). The training and adaptation of new principals of education institutions for work in education institutions. Summary of the Promotion Paper. Latvijas Universitāte. 